\title{
ETHNIC HUMOUR: WHAT DO PORTUGUESE PEOPLE LAUGH AT?
}

\author{
Pedro Martins
}

\begin{abstract}
The concept of ethnic humour may be defined as a type of humour in which fun is made of different traits (especially personality, behaviour and customs) of a group and/or its members thanks to their social, political, cultural and economic background.

Within Portuguese society we may find numerous jokes, riddles and puns about several nations and countries with which Portugal, by virtue of its historical past, had some kind of connection. From an anthropological perspective it is then particularly interesting to try to identify the reasons hidden behind each and every nation's selection. By recalling the three major humour theories we are sure that the jokes, riddles and puns were especially generated either to release tension regarding a tragic situation or to reveal the incongruity of certain behaviour, thus showing Portuguese superiority over the other nations.

It is therefore the aim of the article not only to introduce and share with you a part of Portuguese humour but also to analyse what may be the particular cause of its original creation and today's usage.
\end{abstract}

Key words: ethnic humour, humour, Portuguese culture, Portuguese humour

\section{PART I}

\section{On the concept of humour}

In order to better approach the concept of humour we shall try to answer three main questions regarding our topic: 1) what is humour; 2) why do we laugh; and 3) what do we laugh at?

\section{1) What is humour?}

There is unfortunately no direct answer to this query.

Despite the efforts of many researchers, from different fields of expertise (philosophy, anthropology, psychology), there is no univocal or consensual definition for the word humour. 
It may be interpreted as a biological and instinctive action and reaction to social and communicative behaviour, as a joyful state of mind or simply as something we are able to identify but not define (cf. Darwin 1965; Dearborn 1900; Oring 2003; Sully 1902).

If we were to present our own explanation, we would probably say humour is the ability someone has to amuse him/herself, or others, according to a cognitive stimulus-response mechanism.

Laughing (or at least smiling) is also naturally related to this framework but it is not its standpoint. In other words, since we laugh in many other situations, laughter rather than the essence of humour should be considered as its physiological consequence and its external manifestation.

\section{2) Why do we laugh?}

Based on our previous statement laughter, together with other traits as language and tool making, is usually seen as a characteristic unique to human beings (cf. Apte 1985).

The complex facial expression associated with laughter is a result of a natural coordination between eyes, cheeks, mouth and vocalisation and may occur for many and different reasons. Whether part of the socialisation process or not, laughter may be observed as a reaction to tickling, laughing gas, to someone else's laugh, etc.; as an expression of joy, anxiety and/or irony; and, particularly important to our subject of course, as a response to humour (cf. Goldstein \& McGhee 1976).

According to the three major humour theories as developed by David Hector Monro (1988) people laugh either to release tension and accumulated energy (Relief Theory), to reveal the absurd of certain behaviours and situations (Incongruity Theory), or to show superiority over others (Superiority Theory).

The Relief Theory was firstly presented by Herbert Spencer in 1860 (cf. Spencer 1881). According to this author, in one way or another, during our daily life we accumulate energy from several sources that in the end must be somehow released. This excitation tends to stimulate muscular motion which is usually expressed through its easiest channel - laughter.

At the beginning of the 20th century Sigmund Freud (1928) approaches this same idea claiming, however, that laughter as a consequence of humour has its own source in energy which otherwise would have been employed to repress sexual and hostile feelings.

In this manner, and in both cases, laughter acts as an escape valve for our negative compressed energy. 
The Incongruity Theory is probably the most famous one since it is related to the most typical laughing factors: non-sense and absurdity.

In fact, in accordance with this theory first introduced by Aristotle (1996) and later developed, among others, by Immanuel Kant (1951) and Arthur Schopenhauer (1969), laughter results of a reaction to an unexpected outcome. The surprise element, that suddenly transforms an apparently normal situation or behaviour into something absurd, usually makes us laugh.

From a social perspective, laughter due to incongruity may also act as a very strong social corrective. On one hand it helps community members to recognise the faults and undesired actions of their peers and, on the other hand, by discriminating against those who do not live by the established rules, contributes to the creation of a constant pattern within the entire society.

The Superiority Theory is based on the fact that people laugh in order to reveal their triumph over other people or circumstances.

Whenever we feel less foolish, ugly, unfortunate or less weak than our peers, a sense of euphoria is generated inducing us to laugh.

Thomas Hobbes (2005), probably the best known superiority theorist, talks of laughter as a sudden glory arising from the conception of some superiority in ourselves by comparison with the inferiority of others or with our own former situation. This is what we could also call the joy of victory, the typical "Ha, ha!" response after defeating someone's idea, thought or argument.

These three perspectives, however, do not represent the entire theoretical framework. As a matter of fact, they should not even be considered as rivals; on the contrary, they are to be seen as truly complementary to each other.

\section{3) What do we laugh at?}

The answer to this question is very subjective. Humour is a personal feeling and follows no logical thoughts.

In a single and general sentence we could, however, borrow Henri Bergson's perspective and state that the comic element does not exist outside of what is strictly human (Bergson 1980). In other words, everything can be humorous as long as it may be humanly and intellectually analysed. What we are trying to express is that we may laugh at everything because we (human beings) are able to judge everything that surrounds us in a funny way. If we laugh at an animal, or even at an object, it happens only because we are giving to it a human and humorous use and interpretation.

Nevertheless we could also definitely point out some other factors which normally would make us laugh, namely: 1) repeated actions, 2) snowball effects, 3) deformations, 4) absurdity, 5) exaggeration and 6) language itself. ${ }^{1}$ 


\section{On the concept of ethnic humour}

Ethnic humour may be defined as a type of humour in which fun is made of different traits of a group and/or its members thanks to their social, political, cultural, religious and economic background (cf. Apte 1985).

According to Christie Davies "the term "ethnic" tends to be used in a broad way about a group that sees itself and is seen by others as a people with a common cultural tradition, a real or imagined common descent, and a distinctive identity" (Davies 1990: 1). The most frequently mentioned topics, within ethnic humour, are therefore geographic origin, ancestors, customs, religion, race, language and physical attributes (Apte 1985).

Despite its apparently inappropriate use - it is in fact easily accepted that besides discriminatory feelings, "ethnic humour may conceal malice and allow expression of aggression without the consequence of other overt behaviours" (Apte 1985: 140) - it is simultaneously true that ethnic humour gathers many other social and psychological functions: 1) it may substitute physical aggression, 2) express social criticism, 3) help the preserving, defending or enhancing of the ego of a certain community, and at the same time 4) it may also simply entertain.

Whenever we tell a (ethnic) joke making use of commonly used techniques such as over-generalisation, stereotypes, exaggeration of gestures, accents, deformations and so on we present a "misleading tale that begins as a plausible account of a real people and then switches to an absurd script based on a wellknown, established convention" (Davies 1990: 320). ${ }^{2}$

We have therefore a precise and identified mock target that, even if replaced according to the speaker's will and necessity, will always play an exact and determined humorous role; we mean that as long as the contextual determinants subsist - nature of the considered society, type of contact and interaction between addressed and addressees, historical motivations, etc. - ethnic jokes will always persist.

\section{PART II}

\section{On Portuguese humour}

In this second part we would like not only to introduce some Portuguese jokes, riddles and their respective mock targets but also to understand why the Portuguese people tend to laugh at them. 
These are the results of personal choices and interpretations, we confess, but only within the scope of better illustrated part of Portuguese humour and culture. They do not represent the author's way of thinking.

The following jokes were divided into six different groups according to the targeted origin or nationality (Chinese, Russian, Brazilian, African, Spanish and Portuguese).

Their vehicular language is naturally Portuguese and even though many translation theorists say it is impossible to translate a joke, we have done our best trying to render them into English - all the translations are therefore our responsibility. All jokes may be easily found on the World Wide Web in sites dedicated to Portuguese Humour ${ }^{3}$.

\section{1-2) Chinese and Russian people}

There are actually not so many jokes on these nationalities as the contacts Portuguese people had with the citizens of those countries are rather few. Still, Portuguese nationals take advantage of phonetic similarities between all three languages in order to stimulate the sense of humour among their peers.

Since their contents mostly regard linguistic and phonetic aspects we may classify it as ethnic humour based on language attributes, however, we should also affirm there are no malice or offensive thoughts in either case. As we may see, Portuguese people try to amuse their audience answering all questions in an apparently correct form by mixing and playing with Portuguese words that may sound Russian or Chinese, at least to a Portuguese speaker.

Their goal is therefore simply entertaining:

- Do you know how you say "mother-in-law" in Russian? [No]

- Sóstorva!

[In Portuguese: Só estorva - 'she only disturbs']

- Do you know what the name in Russian is for "someone who is about to die"? [No]

- Pépakova!

[In Portuguese: (Com os) pés para a cova - 'to have his/her feet towards/ near the grave']

- Do you know how do you say "vacuum-cleaner" in Chinese? [No]

- Limpópó!

[In Portuguese: Limpa o pó - 'it cleans the dust'] 
- Do you know how to say "your hair is dirty" in Chinese? [No]

- Sen Chan Pô.

[In Portuguese: Sem champô - 'without shampoo']

\section{3) Brazilian people}

According to the jokes we are about to consider, Brazilian people, on the contrary, are regarded with malice. As in most cases of ethnic humour, based on physical and psychological attributes, Brazilians are here criticised and discriminated against for their lack of intelligence. It represents therefore a clear example of the Superiority Theory which, in this case, may also be linked to the historical relations between both countries. If previously Portugal used to dominate and subjugate the Southern American territory, as well as its people, for almost four hundred years (16th-19th centuries), lately (especially in the last decade) Brazil's economic and political role became everyday more and more important. This new and unexpected reality stung Portugal and its national pride and status so that Portuguese people had to create different ways to claim their (pseudo) superiority over their former colony:

Two Brazilian people were admiring the Colosseum in Rome...

- My God! Isn't that amazing?

- Oh yeah! Now just imagine when it will be finished!

A Brazilian citizen was catching a plane to go back to Brazil. He had a second class ticket but he was trying to travel first class. The hostess noticed his deception and approached him saying more than once he would have to go back to his assigned place. But the man was stubborn and replied he wouldn't go anywhere. He wanted to travel first class no matter what. Without knowing what else to do, the hostess called the captain. When he came next to the Brazilian, he whispered something to his ear and the man immediately ran back to his place in second class. Watching this situation the hostess was very surprised and asked the captain:

- Excuse me, captain, what did you say to him?

- Oh well, I simply told him first class was not going to Brazil! 


\section{4) African people}

The following two ethnic (racial) jokes were particularly common during the Portuguese Colonial War in Africa (Angola, Guinea and Mozambique) in the 1960s and the 1970s. Thanks to both examples we may observe, firstly, the use of the Superiority Theory in order to disgrace the poor and badly nourished nationals of the Portuguese ex-colonies in Africa who could not easily have access to meat and, secondly, the need to enhance awareness and relieve Portuguese people and soldiers about typical and tragic war situations such as stepping on a landmine. By making use of this kind of humour Portuguese nationals were trying not only to sustain their spirit and morale but also to convince themselves that they were stronger and more powerful than Africans:

- Do you know when a nigger eats meat? [No]

- When he bites his own tongue!

- Do you know when a nigger reaches a higher level in his life? [No]

- After stepping on a landmine!

\section{5) Spanish people}

In the next two examples we may observe malice is once again present in Portuguese jokes. If we consider rivalry has always been part of the PortugueseSpanish relations, it is not surprising that Portuguese nationals use humour to criticise the neighbouring country either to stimulate and/or enhance the Portuguese ego. Despite the geographical, historical and language proximity between both countries, the previewed jokes show that Portuguese people may be very hard on their Iberian "brothers"/neighbours and, as in the second example, even launching them out of an airplane. Within the second situation an extra cultural explanation regarding Aljubarrota is due: at the end of the 14th century Portugal was facing a serious succession problem as after King D. Fernando's death his only female child was married to the King of Castile. If on one hand there were people interested in the unification of both kingdoms, on the other hand the majority of the Portuguese nationals desired that Portugal remain independent. Thus, being in such a situation and in order to mark his position, the King of Castile decided to invade Portugal but he was completely defeated by the Portuguese soldiers in the famous battle of Aljubarrota. Therefore, Aljubarrota stands as a sign not only of Portuguese independence but also of Portuguese superiority over Spanish people. 
Before the visit of the Spanish Prime Minister to a Portuguese school, the teacher decided to prepare his students for the welcoming ceremony for his distinctive guest.

- OK children, you have to be very polite with the Spanish Prime Minister, do you understand?

- Yes, sir...

- And when I'll ask you what do you think about Spain, you'll say Spain is a very good friend of ours, OK?

- Yes, sir...

But Joãozinho stood up and replied:

- No teacher, we should say Spain is like a brother to us.

- I see, but you don't have to exaggerate. Just say it is like a friend to us.

- No, no, like a brother!

- But Joãozinho, why do you insist we should say Spain is like a brother and not like a friend to us?

- Teacher, it is simple, because friends we can choose!

An Englishman, a Frenchman, a Portuguese and a Spaniard are on a plane. Due to an engine breakdown and after getting rid of all the cargo, the captain tells the four passengers that only one can remain onboard and that the other three would have to put their parachutes and jump out of the plane.

After a moment of silence, the Englishman steps to the door and before launching himself off the aircraft screams: "Long live the Queen!"

After him comes the Frenchman and just before launching himself off the plane says: "Long live Jeanne D'Arc!"

And then comes the Portuguese and screams: "Long live Aljubarrota!" throwing the Spaniard through the open airplane door.

\section{6) Portuguese people}

Portuguese people can also be very critical about themselves.

According to the Relief Theory and Incongruity Theory, we may naturally argue the next three jokes are no more than ironical but it is also defendable that they rather reveal a very strong social critique with two main interpretations: on one hand, they represent an opportunity to point out different faults, incongruities and defects of the Portuguese society as well as that of its members and, on the other hand, they work as a social reaction so that the negative aspects of the Portuguese community may be minimised and eventually 
accepted. Laughter is thus supposed to stand as the true remedy towards the enhancement of society:

An Englishman, a Frenchman, and a Portuguese travel together throughout Europe...

The Englishman:

- Oh, I think we are in London...

- Why do you say that? (ask the other two)

- There is Big Ben!

A couple of days later the Frenchman says:

- Oh, I think we are in Paris...

- Why do you say that?

- There is the Eiffel Tower!

A week later the Portuguese also has his say:

- Oh, I think we are now in Lisbon...

- And why do you say that?

- Someone has stolen my wallet!

The Heads of State of Portugal and Switzerland meet each other at a European summit...

The Portuguese Head of State introduces his team to the Swiss colleague:

- These are my Health, Education, Culture and Justice Ministers.

- Nice to meet you all. (replied the Swiss delegate)

And then he introduced his own team:

- And these are my Health, Agriculture, Education and Navy Ministers.

The Portuguese suddenly laughs at him and asks surprised:

- I am sorry to interrupt you but... well... if Switzerland has no sea, why do you have a Navy Minister?

- What do you mean!? (replied the Swiss Head of State) When you have introduced your Health, Education, Culture and Justice Ministers, I haven't laughed, have I?

After being captured, a Frenchman, an Englishman, an American and a Portuguese face a firing squad...

The French prisoner takes his place before the soldiers and thinks of a way to avoid his death. When he heard the word of command "Reaaaaaaaadyyyyyy..." he decided to scream "Earthquake!" and everybody ran away... 
When the English prisoner's turn came, he was ready to use a similar trick. And when the general said "Reaaaaaaaadyyyyyy..." the Englishman screamed "Tsunami!" and everybody left the place...

By the time the American prisoner reached the shooting mark and heard the command "Reaaaaaaaadyyyyyy..." he screamed "Hurricane!" and everybody went away...

At this point it was time for the Portuguese prisoner to face the firing squad. "Reaaaaaaaadyyyyyy..." - "Oh my God... What shall I say..." (thought the Portuguese) "Let's see: Earth, Water, Wind... Hummm... Oh, I know: Fire!” (he screamed)

Last but not least we would like to show that Portuguese people are also very proud of themselves as well as of their capabilities.

As a matter of fact, the Portuguese consider themselves to be particularly successful at getting out of trouble and/or at inventing unexpected solutions, therefore national humour could not ignore this. Our next and final joke points out another clear example of the Superiority Theory in which it is not even important to bring out other nationalities. In this specific case Portuguese humour and competence subsist independently and erga omnes without any need of direct confrontation or opponent. Although this joke could naturally be also related to the theories of absurdity and incongruity, its main goal is definitely to stress Portuguese people's (sometimes involuntary) superior and outstanding abilities:

In a Portuguese elementary school the teacher asks, out of the blue, a pupil who was not paying attention to the lesson:

- You there, tell me two pronouns, quickly!

The boy, very frightened, stands up and says:

- Who? Me?

- Oh, ok... Very good, I thought you were distracted. You can now sit down again, thank you.

\section{CONCLUSION}

In conclusion, and as previously stated, it was our goal not only to introduce and present part of Portuguese humour but also to analyse as to what may be the particular causes for its original creation and today's evocation. 
After having presented the principle humour theories, respective Portuguese jokes and riddles on this subject and the analysis of the major questions regarding humour and laughter, we would hope that Portuguese humour and culture is now much closer and clearer to us all.

\section{NOTES}

1 In order to obtain a full perspective on this specific topic allow us to suggest you six Monty Python sketches that perfectly illustrate the respective given examples: 1 ) "Falling from building"; 2) "Dirty fork"; 3) "Ministry of silly walks"; 4) "Silly Olympics"; 5) "Killer rabbit"; 6) "Argument clinic".

2 Cf. Monty Python sketches, endnote No. 1.

3 Cf. http://anedotas.numsitedejeito.com/, last accessed on 30 March 2012.

\section{REFERENCES}

Apte, Mahadev 1985. Humour and Laughter: An Anthropological Approach. London: Cornell University Press.

Aristotle 1996. Poetics. London: Penguin.

Bergson, Henri 1980. Laughter. Baltimore: John Hopkins University Press.

Darwin, Charles 1965. The Expressions of the Emotions in Man and Animals. Chicago: University Press.

Davies, Christie 1990. Ethnic Humour around the World: A Comparative Analysis. Bloomington: Indiana University Press.

Dearborn, George V. N. 1900. The Nature of the Smile and Laugh. Science, Vol. 11, No. 283, pp. 851-856.

Freud, Sigmund 1928. Humour. International Journal of Psychoanalysis, Vol. 9, pp. 1-6.

Goldstein, Jeffrey H. \& McGhee, Paul E. 1976. La psicologia dello humour: prospettive teoriche e questioni empiriche. Milano: Angeli.

Hobbes, Thomas 2005. Human Nature. In: The English Works of Thomas Hobbes of Malmesbury. Vol. 4. Yarmouth: Elibron Classics, pp. 1-76.

Kant, Immanuel 1951. Critique of Judgment. New York: Hafner.

Monro, David Hector 1988. Theories of Humor. In: L. Behrens \& L. J. Rosen (eds.) Writing and Reading Across the Curriculum. Glenview, IL: Scott, Foresman \& Company, pp. 349-355.

Oring, Elliot 2003. Engaging Humour. Chicago: University of Illinois Press.

Schopenhauer, Arthur 1969. The World as Will and Representation. New York: Dover Publications. 
Spencer, Herbert 1881. The Physiology of Laughter. In: Humboldt Library of Popular Science Literature. Vol. 17. New York: J. Fitzgerald, pp. 253-258.

Sully, James 1902. An Essay on Laughter: Its Forms, Its Causes, Its Development and Its Value. New York: Longmans, Green \& Co. 